Theatre Research in Canada

Recherches théâtrales au Canada

\title{
Through the Fictive to the Real(ish): Affective Time and the Representation of "Real Newfoundland" in Rising Tide Theatre's Trinity Pageant
}

\author{
Kelsey Jacobson
}

Volume 39, Number 1, 2018

URI: https://id.erudit.org/iderudit/1055467ar

DOI: https://doi.org/10.7202/1055467ar

See table of contents

Publisher(s)

Graduate Centre for the Study of Drama, University of Toronto

ISSN

1196-1198 (print)

1913-9101 (digital)

Explore this journal

Cite this article

Jacobson, K. (2018). Through the Fictive to the Real(ish): Affective Time and the Representation of "Real Newfoundland" in Rising Tide Theatre's Trinity

Pageant. Theatre Research in Canada / Recherches théâtrales au Canada, 39(1).

https://doi.org/10.7202/1055467ar

\section{Article abstract}

In this article, Jacobson examines the ways in which the Trinity Pageant in Trinity, Newfoundland, Canada aims to animate local culture through a two-hour walking tour around the town's historic sites that is largely predicated on a sense of realness. Using interviews with audience members and the pageant's director Donna Butt as primary source material, Jacobson considers the perception and function of realness in the pageant's re-enactment. She first uses theories of site-specificity, historical re-enactment, and theatrical time to consider the various forms of the "real" at work in the production. Jacobson then suggests the work that might be accomplished by such affectively real performance, as both a marker and maker of real identity, supported by the theories of Elin Diamond and Erin Hurley. Using concepts from Rebecca Schneider and Tracy C. Davis, Jacobson also argues that the affective time created by the pageant's blending of past history and present-day performance creates a future imperative in which audience members are compelled to save the authentic culture they have just witnessed. Finally, she considers the implicitly conservative preservationist impulse that underscores the pageant's re-enactment to trouble notions of inclusion, belonging, and community.
All Rights Reserved @ Theatre Research in Canada / Recherches théâtrales au Canada, 2018
This document is protected by copyright law. Use of the services of Érudit (including reproduction) is subject to its terms and conditions, which can be viewed online.

https://apropos.erudit.org/en/users/policy-on-use/ 


\title{
Through the Fictive to the Real(ish): Affective Time and the Representation of "Real Newfoundland" in Rising Tide Theatre's Trinity Pageant
}

\author{
KELSEY JACOBSON
}

In this article, Jacobson examines the ways in which the Trinity Pageant in Trinity, Newfoundland, Canada aims to animate local culture through a two-hour walking tour around the town's historic sites that is largely predicated on a sense of realness. Using interviews with audience members and the pageant's director Donna Butt as primary source material, Jacobson considers the perception and function of realness in the pageant's re-enactment. She first uses theories of site-specificity, historical re-enactment, and theatrical time to consider the various forms of the "real" at work in the production. Jacobson then suggests the work that might be accomplished by such affectively real performance, as both a marker and maker of real identity, supported by the theories of Elin Diamond and Erin Hurley. Using concepts from Rebecca Schneider and Tracy C. Davis, Jacobson also argues that the affective time created by the pageant's blending of past history and present-day performance creates a future imperative in which audience members are compelled to save the authentic culture they have just witnessed. Finally, she considers the implicitly conservative preservationist impulse that underscores the pageant's reenactment to trouble notions of inclusion, belonging, and community.

Dans cette contribution, Kelsey Jacobson examine comment le Trinity Pageant, un spectacle présenté à Terre-Neuve, cherche à illustrer la culture locale au moyen d'une visite à pied de deux heures des lieux historiques du village de Trinity qui repose en grande partie sur un sentiment de réalité. En se servant comme source primaire d'entretiens menés avec des membres du public et la metteure en scène du spectacle, Donna Butt, Jacobson s'intéresse à la perception et à la fonction du réel dans la reconstitution que propose le spectacle Trinity Pageant. S'appuyant dans un premier temps sur des théories liées à la spécificité au lieu, à la reconstitution historique et au temps théâtral, Jacobson examine les diverses formes du "réel " qui sont à l'œuvre dans cette production. À l'aide de théories formulées par Elin Diamond et Erin Hurley, elle fait ensuite ressortir le travail que peut accomplir un spectacle reposant sur l'affect de la réalité pour marquer et créer l'identité réelle. Des concepts empruntés à Rebecca Schneider et Tracy C. Davis permettent à Jacobson de faire valoir que le temps affectif créé par le spectacle en fusionnant l'histoire du passé à la représentation dans l'instant présent crée un impératif futur où les membres du public sont appelés à sauvegarder la culture authentique dont ils viennent de témoigner. Pour conclure, Jacobson s'intéresse à la pulsion de conservation qui sous-tend implicitement ce spectacle de reconstitution pour troubler les notions d'inclusion, d'appartenance et de communauté.

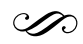


In response to my questions about the realness of their theatrical experience, audience members in post-show interviews repeatedly recall the church scene in Rising Tide Theatre's Trinity Pageant. The scene they refer to is a memorial service for the victims of a sealing disaster, in which spectators slowly file into St. Paul's, a nineteenth-century church, while a choir of performers in period costume sings hymns. An actor dressed as a minister proceeds to give a service in which he describes the "recent" tragedy that has taken several lives from the surrounding community of Trinity, Newfoundland in the winter of 1892 . Indeed, the minister-actor uses historically accurate names as he recounts the victims, reinforcing the apparent realness of the performance. Falling into the familiar ritual, audience members respond back to the minister's call of "Peace be with you," before both choir and audience sing together a closing hymn. Is this just part of a play? Or is it a real memorial service? The questionable realness creates a kind of special time in which historical past feels poignantly present and the audience, together, feel obliged to participate even as they are unsure of the realness of both the church and the service:

AUD ${ }_{3} B$ : And I looked at him and I said "This is not a real church."

AUD $3 \mathrm{~A}$ : This is not a real service, but we just said the real response.

(Aud $3 \mathrm{a}$ and $3 \mathrm{~b} 27$ August 2016)

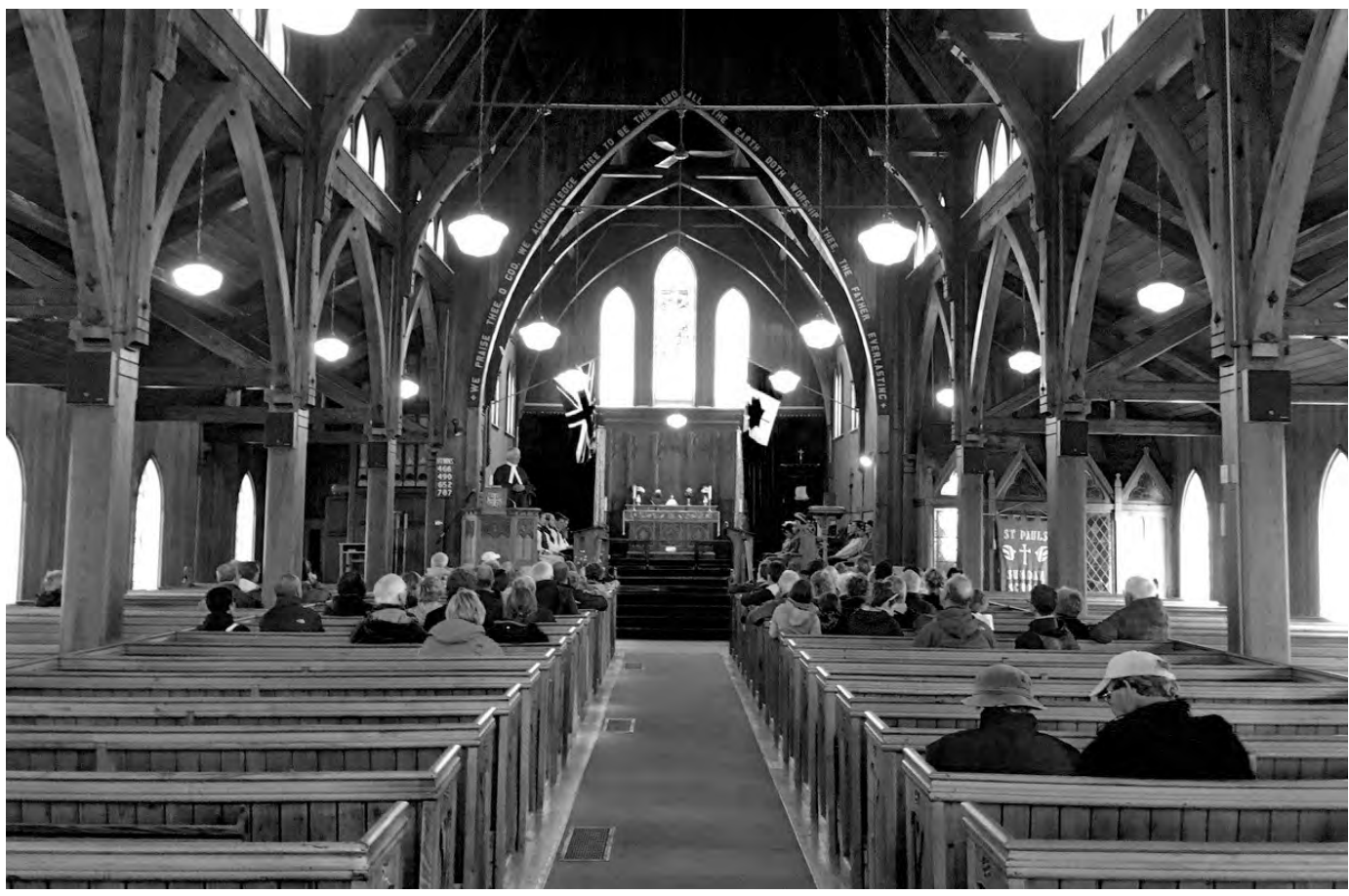

Photo of the audience seated in pews in St. Paul's church interior. Photographer: K. Jacobson

Using theories of theatrical time, affect, and cultural preservation from Erin Hurley, Scott Magelssen, Rebecca Schneider, and James Overton, coupled with data from interviews 
with audience members and the pageant's director, this article argues that the pageant utilizes notions of "real-ish-ness" to animate the history and culture of Newfoundland and vouch for the creation and maintenance of a special "Newfoundland time." The pageant relies on ostensibly real content as it re-enacts moments from the town's history in real, present-day, site-specific locations, and it animates real audience members to contribute to the town's tourism economy that is dependent on this commodified version of Newfoundland history. The pageant thus blends past, present, and future into a weave of performative time that is both affectively and effectively real for audiences. The creation of this kind of affective temporality is similar to Sara Ahmed's concept of an affective economy, which has the power to "do things" and "align individuals with communities - or bodily space with social spacethrough the very intensity of their attachments" ("Affective Economies" II9). Affective time, then, is the construction of a particular blended temporality in which affects are in turn able to better "bind subjects together" (II9), or, in other words, affective time allows for the creation of an affective economy. The pageant's temporal blending in this case results in engendering a maintenance of Newfoundland culture such that, as Artistic Director Donna Butt suggests, "we [as audience members] are a part of the story," caught in this cross temporality and motivated to preserve the unique Newfoundland culture we've just witnessed (Butt). I will here argue that the pageant's "real-ish-ness" moves to create a kind of temporally-based affective economy, before further considering what communities and bodies are resultantly included or excluded in the pageant's selective use of the real.

\section{Finding Time: The Trinity Pageant's History and Operation}

The Trinity Pageant has been the anchor event of Rising Tide Theatre's annual summer theatre festival for the past twenty-four years, running from May to early September. The two-hour promenade performance sees audiences follow a large cast of actors around the small outport town of Trinity in northeast Newfoundland to several, primarily outdoor, performance locations including the church graveyard, two different beaches, and green spaces next to restored historical buildings. Various historical time periods are represented in the ten scenes, which range from a direct address monologue by Sir Richard Whitbourne, the author of $A$ Discourse and Discovery of the Nere Founde Lande who first came to Trinity in I579, to a scene dramatizing the local governance election of I832. The Pageant's popularity must also be noted; the show's audiences range from fifty to 150 every performance, rivalling the entire town's population of 169 (according to the 2016 census).

The overall tone is one of pride, showcasing the historical struggle, hardship, and resultant "grit" of the Newfoundland people who face starvation from dictatorial fishery owners and the loss of loved ones who are claimed by the ocean or harsh winters, but who ultimately persevere and create their own Newfoundlander culture and distinct sense of humour. Over the course of the pageant, audience members meet early eighteenth-century settlers who were the first to inhabit the island year-round and, we are led to believe, were a feisty and flirtatious group, as well as a series of pirates, a local religious Quaker, a mourning widow, the district's court magistrate, down-at-heel fishermen, and finally local nineteenth-century politicians. The piece is very much an ensemble production; each scene introduces one or two primary characters, with large portions of the rest of the cast filling it out as "back- 
ground" or running ahead to set up the next scene. The entire company of actors hired for Rising Tide's repertory season of eleven shows, in fact, all perform in the pageant. This is true without exception, as is the fact that all performers hired must have ties to the local area through family, education, or other work.

Artistic Director Donna Butt points to how the inauguration of the Trinity Pageant allowed her to hire people "from the area," helping to provide work for locals. Her overall aim even today, she says, is for "People [to] have as much opportunity as possible to live and work in their province," or, in other words, she is creating theatre that has a very real future effect for the island's inhabitants in the form of economic generation and stability (Butt). Rising Tide's Trinity Pageant was, after all, born in the wake of an intense economic struggle following the 1992 cod moratorium that "hit the population hard" (Butt). On 2 July I992, John Crosbie, the Canadian Federal Minister of Fisheries and Oceans, announced a complete halt to fishing for northern cod in Newfoundland. The provincial government at the time publicly predicted that 19,000 fishers and plant workers would be directly affected and another 20,000 indirectly (Steele et al.35), while Heritage Newfoundland estimates 30,000 people were put out of work, and states that the moratorium ended a 500-year old industry and "a way of life that had endured for generations in many outport communities" (Higgins). In their analysis, Steele, Andersen, and Green refer to various observers commenting at the time that Newfoundland "would lose its small outport way of life and distinctive culture" (35). Both broadly in terms of culture and specifically in terms of job loss, many Newfoundlanders were perceived of as being at risk, and Newfoundland itself was perceived of as being out of time: the end of an industry, and a way of life.

The pageant, notably, manages to capitalize on this notion of being "out of time" and reframe it positively: it presents a special "Newfoundland time" that is indeed out of the time of modernity and the rest of Canada. Even from the first page in the 2016 season brochure, titled "From the Artistic Director," audiences are encouraged to "Come to our 'time' and celebrate our heritage and culture set against the magnificent backdrops of Trinity Bight, where the past and present meet as surely as the waves embrace the shore and the moon shines on the harbor [...] You'll cherish the memories all winter long" ("Rising Tide Brochure"). In this introduction to the work there is immediately invoked a particular time, removed from the vagaries of 'real time,' which Rising Tide Theatre alone has: "Our 'time." This unique time is beholden not to the linearity of past and present, as the two will "surely meet," reinforcing again the notion of a special performance time. There is also a sense of a broad timelessness and surety with references to the natural landscape in which "the waves embrace the shore and the moon shines on the harbor" that seem to invoke the aphorism "the sun will always rise." This continuous time is so affecting, in fact, that the audience will carry their memories into the approaching winter, invoking an almost riddle-like sequence of temporal events: a potential future filled with past memories that will be made in the reader's future attendance at a performance about the past. In the face of the perceived loss of a way of life, the Trinity Pageant creates an affective temporality that includes both a gesture backwards to re-enact lost time through real history, and forwards in its attempt to recapture time in the form of real employment and economic futurity. The result is a special time, absented from the modern world and yet generative of it, achieved through the use of elements of real history, site-specificity, and the resultant economic generation through the tourism industry. 


\section{Affective Time and Site-Specificity: Real-ish Re-Enactment}

It is important to begin an examination of the pageant's re-enactment of historical events from the town's past with a brief discussion of the complex relationship between authenticity and re-enactment in the wider living history movement. Alan Gordon, in his writing on living history museums in Canada, suggests that authenticity is one of the dominant values of the entire living history movement (15). In Living History Museums: Undoing History Through Performances, Scott Magelssen similarly describes that "the fundamental notion of time and its relationship to human experience at these sites remains the same: visitors are still encouraged to believe that they are entering an accurate, authentic representation of the past upon crossing the threshold into the living history museum exhibit" (22). While the Trinity Pageant has a unique relationship to authenticity insofar as it is clearly and self-consciously a play, it does attempt to enact historical record and still invites a stepping into a different, authentic time. This different time, however, is not necessarily a specific historical period: we, as audience members, are aware of the theatricality of the production, and own our place in the present day. Instead, the "real" past meets our present moment of watching in a kind of blended temporality, as in the church scene described at the beginning of the article. This creates a different sense of the "real" than the authenticity Magelssen and Gordon describe. The Trinity Pageant is not seeking exact historical accuracy, but a "realness" born of the perception of an authentic culture, sometimes at the cost of historical fact, exclusionary practice, and misrepresentation. The clear impetus is not on re-creating an accurate historical past or authentic experience of a past time, but on creating for present-day audiences an experience that affectively feels real, in this time. I thus here use "real" as a term that suggests the perception of realness by audiences and, rather than limit this to considerations of reality or authenticity, I tend toward using the term real-ish-ness: something that feels real even if it is not entirely factually, historically, or truthfully real.

One particularly evocative scene from the Trinity Pageant that serves to illustrate this complexity of authenticity takes place on a beach where actors portraying eighteenth-century Reverend Balfour and a contingent of labourers working to clean and dry codfish on flakes are positioned in the still-active port where local fishermen keep their boats. Though the actors in the scene are essentially miming the process of drying and cleaning the fish flakes using fake fish, the method they are enacting is the "authentic" method. They perform their labour by hand, and thus re-enact a part of the Newfoundland cod-fishing identity and tradition: a kind of everyday experience that has all but disappeared along with the Newfoundland cod-fishing industry. One day during performance, a few Trinity locals positioned near the scene were actually cleaning fish while the performance was being staged (Performance 2r August 2016).

These modern-day fishermen on the dock really were cleaning real fish, approximating the traditional methods, but using plastic gloves and ready-made tables. In other words, the performers with their fake fish use authentic methods, while the fishermen with their real fish mix historical and modern methods. The question then arises: which of these is more real-ish, the real fishermen with their modern-day tools, or the theatrical recreation using real, traditional cultural practices? To further complicate questions of which method might be most real, Artistic Director Donna Butt related to a questioning audience member that the actors used to use real fish as props, but that they are getting harder and harder to source; 
the fake stand-in is more readily accessible than the real fish (Performance 27 August 2016). A characteristic feature of simulated heritage and commemorative performance in general is, indeed, a complex and tenuous relationship to the real. Writing on battle re-enactment, Leigh Clemons, for instance, describes how

They cannot be considered battle simulations, or aspects of hyper-reality, as there is a historical event to which they each refer. Yet they are not specifically historical, either, because they are reoccurring in present times, causing a rupture between the signifier and signified. As a result, reenactment and the history it purports to enact are trapped together in a symbiotic relationship of clarification and determination. (Io)

It is thus not immediately clear by which standards we ought to measure the realness of the cleaning and drying of the cod flakes; which is a more accurate representation of the real Newfoundland?

There is, in fact, a "Real Newfoundland" already claimed and described by the tourism industry. Stemming from Newfoundland's resistance to amalgamation with the rest of Canada until 1949 there is a prevailing notion of a special culture: "Among Newfoundland's favourite myths is the belief that we have in this Province a very distinctive and flavourful culture which should be preserved at all costs. Even the Government subscribes to the belief, offering annual prizes for the encouragement of arts and letters" (O'Dea). This culture that ought to be preserved "at all costs" is characterized by James Overton, a political scientist focused on Newfoundland economy and culture, as the "Real Newfoundland," packaged for use in the tourism economy as a sort of romanticized and sanitized presentation of primarily rural and historic Newfoundland. This "Real Newfoundland" encapsulates the majority of the government's tourism efforts in the late-twentieth century (Parsons; Chafe), in which the rural, outport culture of the province is lauded as an authentic and genuine tourist experience. This "Real Newfoundland" is enacted similarly in the Trinity Pageant and its comparable emphasis on the (re)enactment of a particularly local brand of historical Newfoundland. The real Newfoundland performed in the pageant is perhaps, then, not so much real because of its selective use of history, but because it falls into a similar kind of romanticized, nostalgic, or mythologized Newfoundland: it feels more real than it is.

It is clear from this article's analysis that the "Real Newfoundland" presented in the pageant is not necessarily factually real. In the pageant, the audience is introduced to documented historical figures but also to pirates in a scene described in the program as "not entirely historically accurate" but one that "does reflect the amount of pirate activity that was happening in the area." This lack of historical accuracy is not, however, perceived as somehow problematic in relation to the pageant's claims to realness. Rather, in a similar kind of selective facticity, Butt describes: "[The pageant is] real in a number of senses. I think it's a true story [...] I'm not convinced that there is objective history. People are not objective. You write the facts but the facts are influenced by who you are." An audience member corroborates this view, saying that for him, "Historical facts aren't good enough. And, those tales about peoples' joys and pains are very much a part of the history telling" (Aud 4 b 3 I August 20I6). Accordingly, the performance seems to have a meta-level awareness and acceptance, or even celebration, of its own "facticity" or lack thereof. After the scene with the pirates, 


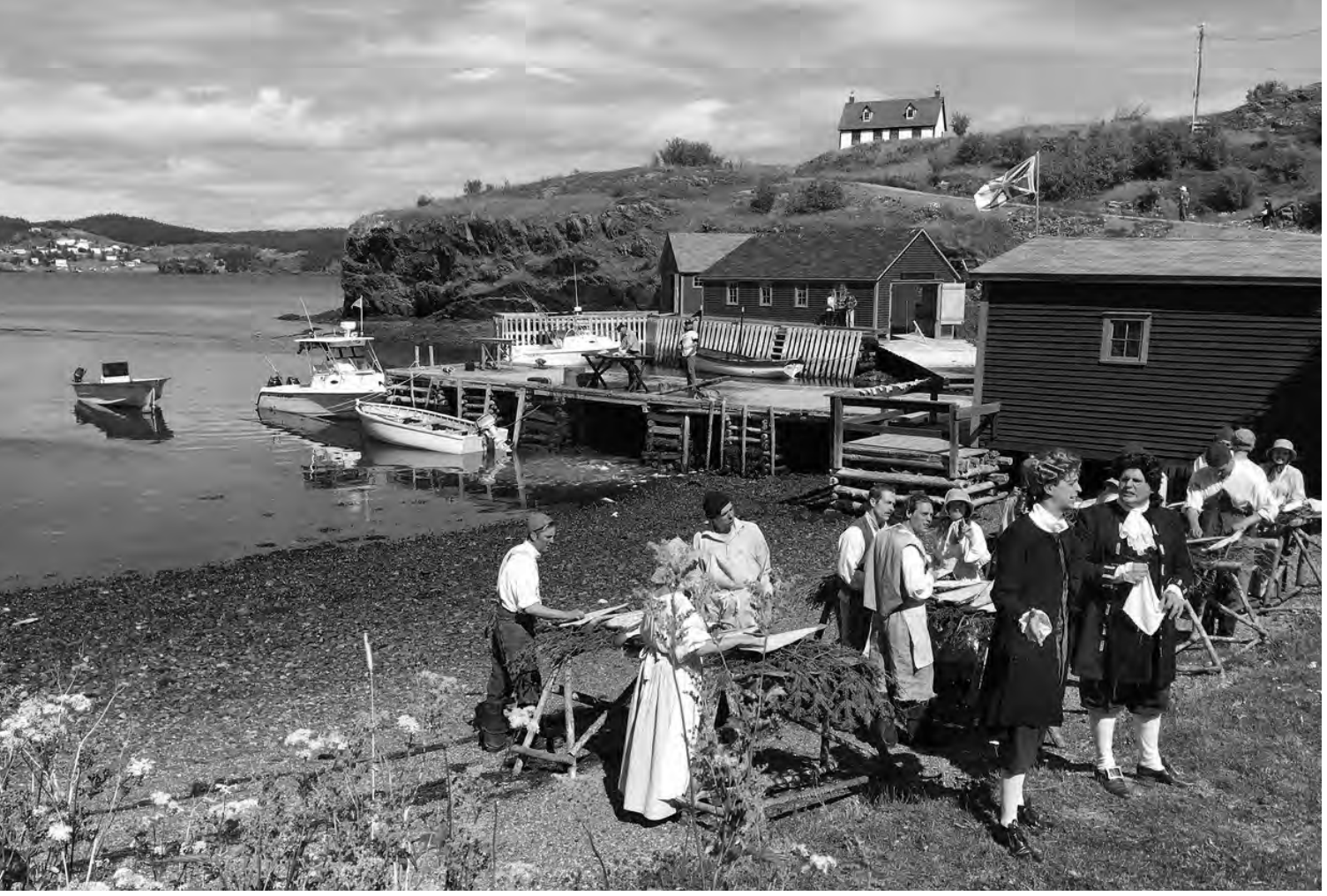

The pageant scene at Harvey's Cove. Actors portraying Reverend Balfour and fishers in 1760 in foreground, local Trinity fishermen in 2016 in background. Photographer: K. Jacobson

for instance, two characters argue about a minor historical fact regarding the arrival of Vikings on the coast. One asserts that their presence in Trinity "has not been proved" while the other replies, "yeah, but we know it happened" (Performance 27 August 2016). The performers here are in fact educating the audience on the codes of what constitutes "true history" during this performance; it is enough that "we know it happened," even in the absence of fact. In this way, "The spectacle, the mythical structure, has some correspondence with actual circumstances and does make many connections with popular views, and sentiments" (Overton, "Real Newfoundland" I22), thereby further strengthening its claims to authenticity or realness. In other words, the pageant's performance fits within the accepted knowledge of the locality, which has taken on its own kind of accepted community-based cultural reality. The historical sense of authenticity as traceable to a real source is less important than the relatability of claims in the context of a community. In this case both the community of Newfoundlanders and their traditions, and the community-of-the-moment created by the audience members, act as arbiters of the real as they judge whether the stories presented are authentic parts of Newfoundland's past. The appeal to the audience to understand historical past affectively rather than factually means that the audience comes to view the real on display as authentically Newfoundland because it feels that way.

In addition to the references to real historical events in the pageant, the use of real, present-day, site-specific places allows for the explicit meeting of two times, past and present, in the same place. Mike Pearson and Michael Shanks, in Theatre/Archaeology, describe sitespecific performances as involving "a location at which other occupations - their material traces and histories - are still apparent” (23). The pageant, for instance, concludes with a scene enacting the election of John Bingley Garland to the District of Trinity in I832, next to the 
historical Lester-Garland house that was John Bingley Garland's real property. The house is now a reconstruction that incorporates the original ruin, funded by the historical society and Newfoundland government. In other words, the other occupations of the site of performance are already multiple in an explicit way for attendees: both the history and the present-day preservation are visible. Indeed, for the Lester-Garland house, even the possibility of future is invoked in the invitation to later visit the house as a ticketed tourist site.

A meeting of time, however, occurs not only in the representation of historical situations like the 1832 election but also in the reflective experience of the audience members themselves. The choice to perform in real spaces is for Artistic Director Donna Butt a means of engaging closely with audiences who are encouraged to consider their own pasts, where they've come from, but also where they currently are and their connection to Newfoundland. As Butt recalls, in writing the Trinity Pageant she wanted to "Write a script that would leave you with a profound sense of where you were." This same impulse is reflected in her choice to perform pageant-style: "You do it outside, it becomes tied to here, this place" (Butt). This phrasing highlights not only the necessity of location, but also how the present-day act of performance engages that location and "ties" it to a very specific time and space. For Gay McAuley, writing on site-specific performance, "spectators experience these places in new ways and are obliged to engage in new ways with the political issues that seem to be an inevitable consequence of being in place" $(\mathrm{I} 7)$. Real place and location become integral to the pageant's engagement with present-day visitors, building an affective attachment that then encourages audiences to consider the current economic, social, and political issues: a scene with Sir Richard Whitebourne is followed, after all, by a reference to the recent hydroelectric Muskrat Falls project.

Butt also, however, highlights the power of specific sites to instigate a reflection on the past: "It's important people know who they are and where they came from. What's running through their veins [...] You belong to this place [...and] need to live in a place you belong and belong to." McAuley also argues that, "Places raise questions about memory and about group and individual identity: who we are is intimately bound up with where we are, and where we come from" ( $\left.\mathrm{I}_{7}\right)$. By virtue of the space, then, audiences are asked to embody the community for a time and consider its issues, becoming at least momentarily identified in relation to the here-and-now, but also to consider belonging and identity in terms of where they "come from" in their past. These questions of identity and belonging, however, imply a very selective and particular past: who "belongs," after all, is a limited category if one considers that the majority of places visited during the pageant are colonial buildings from the Western Europeans who arrived in the seventeenth and eighteenth centuries. Much like the selective historical accuracy at work in the pageant, it is therefore again a kind of qualified, particular real that is at work, with all its resultant politics of identity and inclusion/exclusion.

Similar to the "Real Newfoundland" tourism strategy, which is ultimately less real than mythologized, it must be also be pointed out that the apparent realness of the historic sites is questionable. Many of the scenes cannot take place exactly where their historical antecedents did, and in the case of fictionalized moments there is no "real place" for them to be staged. Audience members were not duped into any kind of misreading of reality, however, as their comments evidence an awareness of the fictitiousness of the performance, or at least the storied nature of it. It was not, for many, the historical fact that was the impor- 


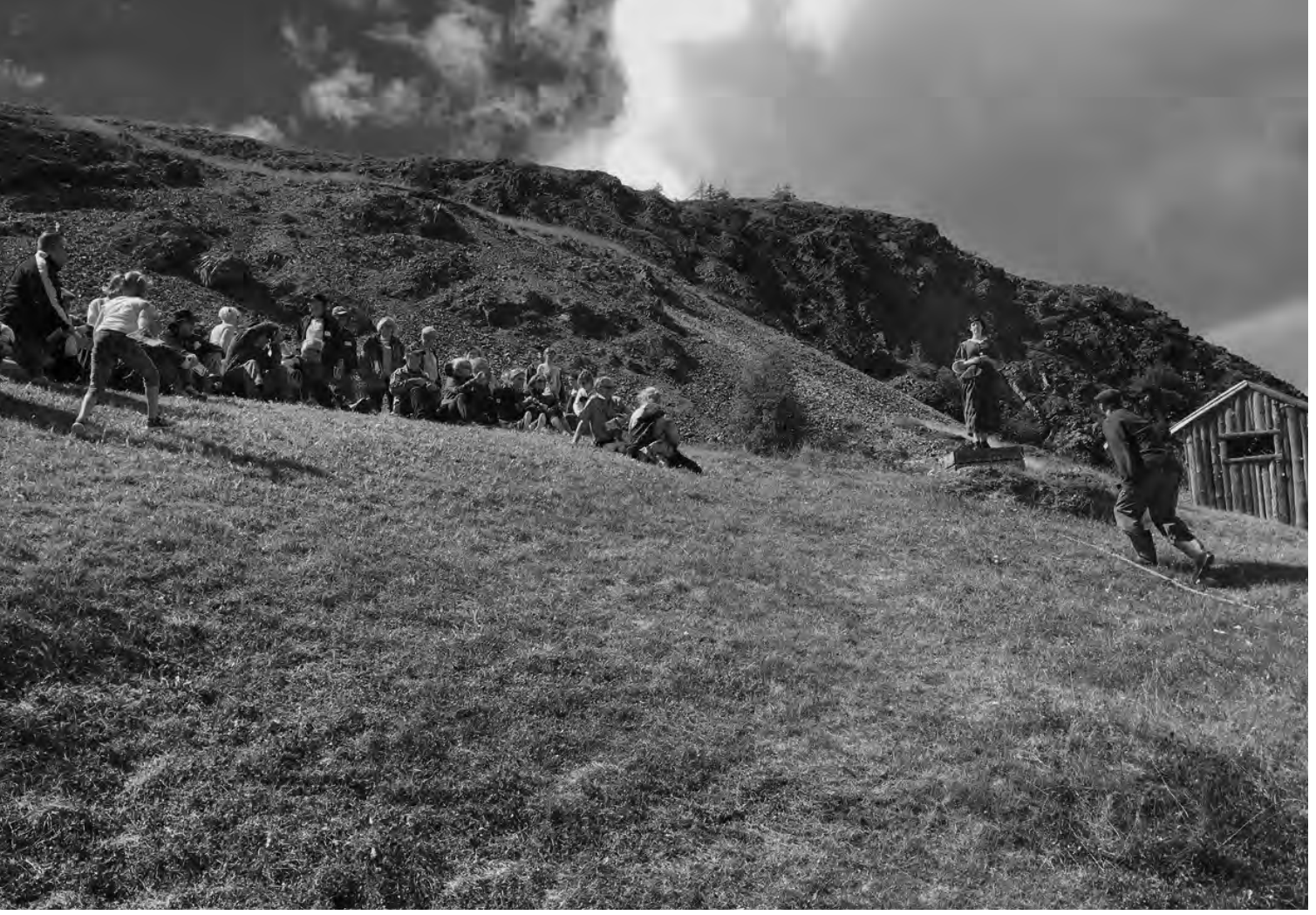

Audience members seated on a hill take in the picturesque natural backdrop of a scene.

Photographer: K. Jacobson

tant aspect, but rather that the located place of the performance had the effect of "bringing life to the history, making it real" (Aud 4а 3r August 2016) in a nuanced paradox differentiating history from the real. Regardless of the stability of the one-to-one relationship between site of performance and site of real history, it is the real affect or the feeling of the potential real that comes from the pageant being located in a particular place that allows for a both/and perception of past and present. Accordingly, Butt describes what she thinks audiences are looking for in the pageant experience as "an experience of Newfoundland, I think they're definitely looking for an experience of a place [...] I think people come to Newfoundland with the sense that it is a separate place. And they expect their experience to somehow reflect this land they've come to" (Butt). The experience of place therefore feels real insofar as it fulfills the already-established notions of what the pageant, and metonymically Newfoundland, is.

This perceived "Real Newfoundland," it should be noted, Overton physically locates in those parts of the province which are remote, like the outport town of Trinity in which Rising Tide is located: "To find the 'Real Newfoundland' visitors are urged to 'go down the side roads' and 'poke into the bays,' to 'turn to the ocean and "test" the breeze; smell the salt, the wave torn kelp, the spray washed air, the saturated, aged sand. The 'real Newfoundland' is the outports," of which Trinity is a prime example (Overton, "Real Newfoundland" II9). Indeed, the performance of the Trinity Pageant takes audience members to the "landwash" (beach) twice, where they can literally smell, taste, and feel the "Real Newfoundland." The importance of the outport, and its culturally contingent status as an exemplar of the "Real Newfoundland," means that the use of site-specific place is a means of solidifying a particular cultural identity. Peter Navarez further suggests that Newfoundland outport culture follows 
Robert Redfield's model of a "folk society: an oral-aural community that, among other characteristics, is spatially "small" and "isolated" (I29). Navarez writes that such a culture is predicated on continuous time and discontinuous space. This is opposed to the fast-paced culture of present day, considered to be one in which time is discontinuous ("now" and "immediate"), and in which globalization and technology fuel connections between far-reaching places and contribute to increasingly continuous space (Navarez I29). The pageant's site-specificity, then, not only encourages a meeting of times both in terms of historical events and personal experiences, but also serves to further confirm Newfoundland's special, slow time, closely tied to its particular place.

\section{The Work of Real-ish-ness}

The stakes emerge when we consider the power of cultural identity as both a communityand nation-building project; the pageant has the potential to become a self-referential mythology of "Real Newfoundland" that mimetically performs and builds identity. As Overton writes, "the significance of mythologies which deal with cultural origins and distinctiveness" are primarily of value in nation-making ("Real Newfoundland" I33). Further, he writes, "it is the vision of the province enshrined in the 'The Real Newfoundland,' which is largely the mythical core of the emerging national culture. As an image it is a symbol for all that is distinctive and essential about the Newfoundland character and way of life" ("Real Newfoundland" 133). In the wake of the intense economic downturn caused by the fishing crisis in Newfoundland in the I990s, the fight for "survival meant the survival of Newfoundland as a distinctive political and cultural entity" (Overton, "A Future in the Past" 64). The maintenance of Newfoundland's distinctive identity, then, can potentially be achieved deictically through cultural performance or mythology: the representation of something onstage that refers to something and thus solidifies that referent as real or, as Hurley articulates, "[g]ranting the nation referent status through performance [that] effectively establishes the offstage 'nation' as fact" (22). To perform, in real time, real space, and with real bodies, lends realness to the events themselves; it shows this is possible, this is maybe how it played out. At the same time, the theatricality gestures away from the performance here and now as if to suggest that there is a less theatrical, more real referent to which it gestures. In this way, the real history at work in the Trinity Pageant, as one such instance of a pointing-back performance, is not so much real by definition, but by operation. It is the mimetic operation suggested by Elin Diamond that is not so much a reference to, but a generating action: "both the activity of representing and the result of it-both a doing and a thing done; both the generative embodied activity of representing [...] and a (true) representation (of a model)" (v), making something real by virtue of its place within mimetic action as the perceptual "source" for a model. The relationship, then, is not from the real to the fictive, as in a typical stage representation of something existing within the real world, but through the fictive to the real.

Indeed, to push notions of mimesis even further, this bears a consideration of what it might mean to point back to something that has no past or remembered original model beyond its iterative re-performance. For the historical inventions and fictional liberties of the pageant, the pointing back can only be to itself, to past performances of the pageant, rather than to some distant history. With the pageant now more than twenty years old, the 
act of performance referring back only to other performances cultivates a kind of real material: the pageant as an historical artifact in and of itself. As Magelssen articulates, "Living history museums become monuments that are thought to protect the events they commemorate from passing into a Hegelian oblivion, while in effect surrogating or standing in for the actual events (and becoming more 'real')" (22). In this way, the repetitive gestural, temporal work of the pageant enlivens a real historical past, even if it is not the one we may have initially assumed. Instead of reinforcing the real history of Trinity, the pageant makes real the work of the pageant itself: the fictional pageant becomes a real historical event, to be referenced by future iterations.

Referring to the past as distinct from the future and present, however, still misrepresents the actual fluidity of the performance of the Trinity Pageant, in which fact is punctuated with fiction, past with present, and vice versa. There is a continual pointing both backwards and forwards, in effect realizing or making real both national identity for present day audiences and historical referents from the past. References to court cases from the nineteenth century are coupled with references to modern-day museum exhibits available for visiting. Historical characters interact with audience members, with Sir Richard Whitbourne kissing the hand of a female audience member in one of the first scenes in the show and the pirate characters conscripting young audience members into their pirate band. Rather than a strict one-to-one representational relationship, the mimesis enacted in the pageant is a both/and relationship that moves flexibly between real and unreal. Schneider, writing on historical civil war re-enactors, fittingly offers that "a live reiterative act, such as a pointing finger indicating 'look at that' or 'it happened there' or 'it will happen there,' casts itself both backward (as a matter of repetition) and forward (it can be enacted again) in time" (37). Overton evidences this flexible operation between the temporal worlds in the "Real Newfoundland" tourism plan, with its slogan of turning "the past into the future" ("A Future in the Past" 64), referring to a unique historic Newfoundland, whether mythic, real, or some combination of the two, that both solidifies that historic source as fact and generates resources and income for future industries.

The historical real presented in the pageant is, of course, not so much real as "not notreal": it cannot be excluded as not real, because parts of it are real or might be real. Its ties are to an emotional or affective response and the identity-building operation it may serve for a nation or community as a marker of authentic experience. This necessitates, however, highlighting the potential danger of this form of real-ish-ness: if the local knowledge, complete with its local prejudices, or exclusion of certain bodies and/or stories, comes to stand in for the authentic, then it can potentially become self-perpetuating in a kind of tautological mechanism. Perhaps the government of Newfoundland and Labrador demonstrates this danger best in their 1975 statement that "Nobody has been living in North America longer than Newfoundlanders, so they are rich in folklore, song, and inherited crafts. Fortunately, Newfoundland has been able to preserve this rare culture in the face of spaceage technology, sophistication and industrial progress" (25). This is a highly problematic description, not least due to its blatant overlooking of the Beothuk and Mik'maq peoples populating the region well before and during the European settlement. Such gaps in the otherwise totalizing notion of Newfoundland as a whole culture, distinct and separate, already begin to destabilize any positivist notions of what a "Real Newfoundland" might 
entail by overlooking historical facts of settlement and colonization while implying origin and an original way of life. The simultaneous selective facticity and creative editing of who belongs within that unique culture suggests both the utility and danger of an apparent, though not necessarily factually correct, realness as a means of solidifying national myth for tourist output and nation-making beyond the tourist industry.

\title{
Keeping Time: Future Preservation
}

Returning to the brochure for the Rising Tide theatre season described at the outset of this article, it is worth considering why Newfoundland culture, and the Trinity Pageant in particular, are expressed temporally and what that temporal expression accomplishes. Newfoundland is presented as out of time: both in terms of separate from the time of modernity and a chance for, quite literally, a vacation, but also out of time in terms of running out of time and requiring preservation. In this final section, I argue that the pageant creates a particular Newfoundland time that inspires a future preservation in the form of real audience contribution. As Barbara Kirshenblatt-Gimblett argues,

\begin{abstract}
When a way of life disappears with the [...] economy that once sustained it $[\ldots .$.$] tourism is$ ready to step in. The formula for revitalizing the economy of a depressed region is the resurrection theatre of the heritage industry. While tourist attractions may seem like oases of time out, they are implicated in a larger political economy of transnational flows of money, people and symbolic capital. (2)
\end{abstract}

Indeed, the clash between times is portrayed as one in which time has been lost: modernity has stolen time, or sped up time, and Newfoundland's unique culture is able to pause time. Though it may feel like an "oasis" of "time out," this Newfoundland time requires financial support and is still a part of a larger economy in which time needs money, in the form of real audience contribution.

To return to the fears expressed over the $1992 \mathrm{cod}$ moratorium in which forecasters speculated about the demise of an entire culture and way of life, Overton writes that in the use of "Real Newfoundland" as a tourism strategy, "[a]n idealized rural life is set against the problems of the present and the uncertainty and instability of the future in a nostalgic celebration of the (lost) values of community, simplicity and stability" (Overton, "Real Newfoundland" I29). The preservation of such a place, then, or perhaps to follow the phrasing in the theatre company's brochure, the preservation of such a time, becomes a clear call to act-it must be remembered or lost, compelling audience members to save it. Overton continues on to say, "It is even popular in some tourist literature to introduce the idea of the imminent demise of 'the Real Newfoundland' making it even more urgent for tourists to 'taste' a way of life which is in jeopardy" ("Real Newfoundland" I29). Tourists are encouraged to spend their tourist dollars tasting, and thereby preserving, the real Newfoundland, participating in a future tourist economy that begins, or at least continues, when the pageant ends through restaurant visits, hotel stays, and ticket purchases. The website of Rising Tide, for instance, contains links to accommodation, activities, hiking trails, restaurants, and shopping destinations with the clear implication that the audience of the pageant may feel inspired to pay 
more, to inject tourist dollars into the town in order to avoid repeating the misery of the town following the loss of their previous economic driver. In other words, the past of Newfoundland's particular place becomes in the present performance something that requires preservation in the future. This preserved time does not quite manage to escape "real time," in which economic success remains the dominant force for determining survival.

This future-preservationist impulse is evident in the specific framing of the pageant itself, too. Following Butt's welcome speech to the audience at each pageant, she incorporates remarks that outline the decline of the community: there are "as many people here in winter as here on this block right now," pointing to the sharply declining population of the town (Performance 24 August 2016). She then asks the audience to drop a coin in the historic Trinity church donation box for future roof repairs. An affective surround wherein the pastness of the church building and its need for roof repairs encourages a present-moment action, the dropping of a coin into the donation box, that generates future effect, a preserved building; or indeed, a variety of possible pasts and futures become dependent on present-day choices. Such site-specific performance, Susan Bennett and Mary Polito argue, "converts landscape into taskscape" (8), citing Pearson's argument that:

in the present, [site] it is experienced as muscular engagement but it also involves retentions from the past, as experience and memory; and projections for the future, as hopes, aspirations. To perceive it, is always to carry out acts of memory and remembrance, engaging constantly with an environment within which the past is embedded. (Pearson, "In Comes I" 219)

The situating of the pageant in present day sites thus allows for audience members to experience simultaneously a present engagement but also a nostalgia for or remembrance of the past. Tracy C. Davis further states that the use of performative time "explains the capability not just to show or describe a speculated-upon future as the real world, but also to bring that future into the present, or the past, as a claimed observable effect. The future is citable and thus becomes an imperative" (15I). José Esteban Muñoz likewise describes the "potentiality or concrete possibility for another world" (I), and the imagined capacities of the not-yethere that challenge the myopia of the status quo that can serve as "both a critical affect and a methodology" to bring that "not yet here" into being (4). This then results in a prompting of audiences to act to preserve the special time presented to them as a kind of future-imperative; they become bound up in the affective web created by the meeting of past and present in real space and motivated to bring into being a preservationist future.

The ideological conservatism implicit in a preservation of the past is, however, a necessary object of interrogation, particularly when the past enacted is not so much factually real as affectively real-ish. Writing on civil war re-enactors, for instance, Schneider describes the fraught relationship she negotiates with re-enactors who feel that the South should have won and see the re-enactment as a potential re-envisioning, or at least re-feeling, of what the future might have been (II, 45). Butt created the pageant with the aim of bringing to life the stories of those people whose lives remain unrecorded in official history, such as the working class and women, and this intent certainly serves to broaden the inclusion of Trinity's official past. At the same time, there are, as noted, clear exclusions. It is no accident, certainly, that 
the pageant begins with a performance of the provincial anthem "Ode to Newfoundland." Not all audience members know the words to the song, however, and the anthem is part of a settler-imposed early-twentieth-century history. Further, though it marks the starting point of the pageant, it certainly does not mark the beginning of Newfoundland, and effectively absents the presence of pre-European human activity. The pageant thus similarly attempts to re-write or at least re-feel the past, to use Schnieder's term, but in doing so there are clear implications for continued issues of exclusion into the future.

The "Real Newfoundland" is thus ultimately less real than real-ish; it is a kind of constructed, affective real, and one that Rising Tide's Trinity Pageant makes full use of from perceived real historic content, to the realness of a present-day site-specific location, and finally in its attempts to garner a real result in terms of the growth and maintenance of a strong and healthy tourist economy for Newfoundland. The prediction found in the brochure for the pageant foretells that "you will remember," a phrase that encapsulates what Schneider calls "a more porous approach to time and to art-time as full of holes or gaps and art as capable of falling or crossing in and out of the spaces between live iterations" in its conflation of future act and past remembrance (6). The result is ultimately the creation of a community motivated to preserve a culture perceived to be out of time: both at the end of its lifespan and in need of preservation, and distinct from dominant cultural time and out of step with the modern world. There is a simultaneous looking back, present locating, and future action such that Rising Tide's Trinity Pageant is an exercise in the creation of an affective time that generates a community of bodies motivated to preserve it. This time, however, must be interrogated: what time is it? Or perhaps more appropriately, whose time? The production of cultural identity ensconced within the pageant holds the potential to make visible our continued boundaries, biases, and demarcations of what narratives, bodies, and even facts are accepted or rejected in the production of "real" history, and, resultantly, the real future.

\section{Notes}

I In August 20I6 I travelled to Trinity, Newfoundland and interviewed audience members following my attendance at four different performances of the Trinity Pageant (20, 24, 27, 3I August 20I6). In this work, interviews with anonymous audience members are denoted by number of interview (e.g. Audı was in the first interview, Aud2 was in the second interview), order of speaking (Aud2a was the first speaker in the second interview, Aud2b was the second speaker in the second interview), and date of interview. In total, I interviewed twenty-three audience members, as well as the Artistic Director of the festival, Donna Butt. 


\section{Works Cited}

Ahmed, Sara. "Affective Economies." Social Text 22. 2 (2004): II7-39. Web. Io Dec. 2017.

Bennett, Susan and Mary Polito. "Thinking Site: An Introduction.” Performing Environments: Site-

Specificity in Medieval and Early Modern English Drama. Ed. Susan Bennett and Mary Polito.

Basingstoke: Palgrave Macmillan, 20I4. Print.

Butt, Donna. Personal Interviews. 28 Nov. 2015, 26 Aug. 2016, 3r Aug. 2016.

Chafe, Paul. ' Only an Artist Can Measure Up to Such a Place': Place and Identity in Contemporary

Newfoundland Fiction." PhD dissertation, Memorial University of Newfoundland, 2008. Print.

Clemons, Leigh. "Present Enacting Past: The Functions of Battle Reenacting in Historical

Representation.” Enacting History. Ed. Scott Magelssen and Rhona Justice-Malloy. Tuscaloosa: U of Alabama Press, 20II. IO-2I. Print.

Davis, Tracy C. "Performative Time." Representing the Past: Essays in Performance Historiography. Ed.

Charlotte M. Canning and Thomas Postlewait. Iowa City: U of Iowa Press, 20I0. 142-67. Print.

Diamond, Elin. Unmaking Mimesis: Essays on Feminism and Theater. London: Routledge, 1997. Print.

Gordon, Alan. Time Travel: Tourism and the Rise of Living History Museum in Mid-Twentieth Century

Canada. Vancouver: UBC Press, 20r6. Print.

Government of Newfoundland and Labrador. The Nerefoundland Adventure. St. John's Department of Industrial Development, 1975. Print.

Higgins, Jenny. “Cod Moratorium.” Heritage Nerefoundland and Labrador. 2009. Web. Io Dec. 2016.

Hurley, Erin. National Performance: Representing Quebec from Expo 67 to Céline Dion. Toronto: U of T

Press, 20Io. Print.

Kirshenblatt-Gimblett, Barbara. "Afterlives." Performance Research 2.2 (Summer 1997): I-9. Print.

Lehmann, Hans-Thies. Postdramatic Theatre. Trans. Karen Jürs-Munby. London: Routledge, 2006.

Print.

Magelssen, Scott. Living History Museums: Undoing History Through Performance. Lanham: Scarecrow Press, 2007. Print.

McAuley, Gay. "Introduction." Unstable Ground: Performance and the Politics of Place. Ed. Gay McAuley. Brussels: Peter Lang, 2006. 15-24. Print.

Muñoz, José Esteban. Cruising Utopia: The Then and There of 2ueer Futurity. New York: NYU Press, 2009. Print.

Narvaez, Peter. "The Folklore of 'Old Foolishness'." Canadian Literature ro8 (1986): 125-43. Print.

O'Dea, Shane. "Culture and Country: The Role of the Arts and Heritage in the Nationalist Revival in Newfoundland." Newefoundland and Labrador Studies 19.2 (2003): n.p. Web. 15 Dec. 2016.'

Overton, James. "Promoting 'The Real Newfoundland': Culture as Tourist Commodity." Studies in Political Economy 4 (1980):115-137. Web. I2 Nov. 2015.

-. "'A Future in the Past'? Tourism Development, Outport Archaeology, and the Politics of Deindustrialization in Newfoundland and Labrador in the I990s." Urban History Review 35. 2 (2007): 60-74. Web. 12 Nov. 2015.

Parsons, Jonathan. "Branded Newfoundland: Lisa Moore's Alligator and Consumer Capitalism." Nerefoundland and Labrador Studies 28.I (2013): 5-27. Web. Io Jan. 2017.

Pearson, Mike. "In Comes I": Performance, Memory and Landscape. Exeter: U of Exeter Press, 2006. Print.

Pearson, Mike and Michael Shanks. Theatre/Archaeology. London: Routledge, 200I. Print. 
"Rising Tide Theatre Season Brochure." Designed by Perfect Day, 2or6. Print.

Schneider, Rebecca. Performing Remains: Art and War in Times of Theatrical Reenactment. London: Routledge, 20Ir. Print.

Statistics Canada. "Trinity (Trinity Bay), T [Census subdivision], Nerwfoundland and Labrador and Nerefoundland and Labrador [Province] (table). Census Profile." 2016 Census, Statistics Canada Catalogue no. 98-316-X201600I. Released 3 May 2017. Web. 9 June 2017.

Steele, Donald H., Raoul Andersen, and J. M. Green. "The Managed Commercial Annihilation of Northern Cod." Newefoundland and Labrador Studies 8.I (1992): 34-68. Web. Io Jan. 2017.

The Trinity Pageant Performances. Conceived and written by Rick Boland and Donna Butt, directed by Donna Butt. Rising Tide Theatre Company. Town of Trinity, Trinity. 21 Aug. 2016, 24 Aug. 2016, 27 Aug. 2016. 